\title{
Analyzing Civil-Military Relations in Pakistan and Turkey (2002-2018)
}

\author{
Usman Khan \\ Lecturer in Political Science \\ University of Malakand \\ usman.pol@uom.edu.pk \\ Dr. Jamal Shah \\ Associate Professor \\ Deptt. of Political Science \\ GPGC Mardan \\ Jamalkhattana@gmail.com \\ Dr. Bakhtiar Khan \\ Assistant Professor \\ Department of Political Science \\ University of Buner \\ bakhtiar@uob.edu.pk
}

\section{Abstract}

Pakistan and Turkey have shared many commonalties in their patterns of civil-military relationship till 2002. In the post-independent Pakistan and post-republican Turkey, the civil-military relations have often remained imbalanced. The military of both the republics have remained entrenched in the respective states politics and have exercised a hegemonic role in the internal and external politics of the republics. However, after 2002, Turkey has experienced a different trajectory of civil-military relationship while Pakistan is still passing through the same pattern of imbalanced civil-military interaction. This paper sheds light on these different patterns by comparing the trajectories of civil-military relationship of the two states. It demonstrates that Turkey has been successful in the application of democratic control over her armed forces in recent years while Pakistan besides having shared a similar pattern of civil-military relationship with Turkey (till 2002) is lagging behind in the commencement of democratic control over military. The paper shows that Justice and Development Party' performance (AKP), European Union 


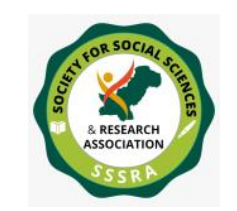

Pak. Journal of Int'L Affairs, Vol 4, Issue 2 (2021)

Analyzing Civil-Military Relations in ...

(EU) criteria, lesser internal and external threats, Erdogan's charisma, continuity in political processes, and factionalism inside the army have been the factors which have contributed to the civilian supremacy in Turkey.

Keywords: Civil-military relations, Coup, d'état, Democratic control, Internal and external threats

\section{Introduction}

Pakistan and Turkey have shared a similar history of civil military relations till 2002. The military of both the states has been involved in politics in one way or the other. The constitutional and political history of Pakistan and Turkey reveals that the two republics have most of the time remained under military autocrats (Khan, 2008). Both states armed forces have shared commonalities in their natures and behaviours. They have been playing a determining factor in the foreign policies of the two republics (Paris, 2010). Moreover, military in both these states have their own economic underpinnings. In Turkey, before 2002, Army Mutual Assistance Association (OYAK) and Armed Forces Pension Fund have marked the emergence of the military as entrepreneur (Schlager \& Weisblatt, 2006). Similarly, the armed forces in Pakistan pursue its own corporate interests which has developed the concept of MILBUS (Military Business) in Pakistan (Siddiqa, 2007). Furthermore, the armed forces of Pakistan and Turkey are the guardians of their respective state ideologies i.e. Islam and Kemalism.

This paper evaluates the hegemonic role of the armed forces of Turkey and Pakistan. It demonstrates that external and internal threats have dramatic impacts on civil-military relationship of the two republics. Civilian institutions failures have also provided a vacuum to men in uniform who remained for a longer time unchecked in Turkey till 2002. Nevertheless, after 2002 Turkey has successfully reduced military dominance to a greater level. On the other hand, the military in Pakistan still influences state politics. The major question the paper addresses is that "Why Turkey has been successful in bringing democratic control over her military since 2002 while Pakistan mostly lags behind in this endeavour?.

In what follows we are giving a brief historical sketch of the civil-military relations of Pakistan and Turkey. Then the factors influencing civil-military relations, and lastly we address our main question of why Turkey has been successful in bringing civilian supremacy over military while Pakistan has been mostly unable in this regard. 


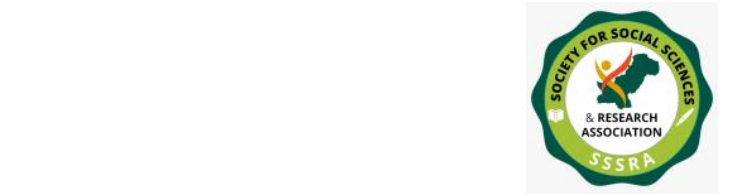

Pak. Journal of Int'L Affairs, Vol 4, Issue 2 (2021)

Analyzing Civil-Military Relations in ...

\section{Civil-Military Relations in Pre-Independent Pakistan and Pre-Republican Turkey}

Being the advocate of modern democracy, the British applied theory of democratic control over military in the newly established colony in 1857 (Rizvi, 2013:12-15). During 1857-1947, the English parliament maintained control over the elite recruitment, public policy, internal security, external defence and military organization (Chamber \& Croissant, 2010).

Likewise, the principle of democratic control had also been observed in the prerepublican Turkey where the armed forces remained subservient to the Sultan (Burak, 2011). During the reign of Sultan, the civil and military institutions were observing the principle of functional specialization. However, their loyalty to the Sultan was affected by the developments that took place in the last phase of Ottoman period. The foremost of these developments were the western type of education, the autocracy of Sultan Abdul Hamid II, the emergence of Young Turks, the war of independence and the establishment of Turkey as a republic in 1923 (Avi, 2007).

\section{Civil-Military Relations in Post-Independence Pakistan and Post-Republican Turkey}

Chamber \& Croissant (2010) explained that Pakistan could not continue with the practice of civilian supremacy over the armed forces. In the subsequent years of the establishment, the civil institutions lost its control on internal security, external defence, public policy and recruitment of elites and all these prerogatives shifted into the hands of military.

According to Rizvi (2013: 11)

"Though the military was integral to the British imperial rule in South Asia and served as its ultimate shield, the military functioned within the parameters set out by the civilian authority and stayed out of active politics. These traditions were accepted as the cardinal principles of military organization in Pakistan. However, with the passage of time, the military expanded its role and established its primacy to the political process which manifested in different forms i.e. active role in policy making from the background, direct rule under the cover of martial law and establishment of civilianized regimes".

After the dissolution of the first Constituent Assembly in 1954, Ayub Khan, the then Commander-in-Chief of Pakistan, was placed in the new cabinet as defence minister. 


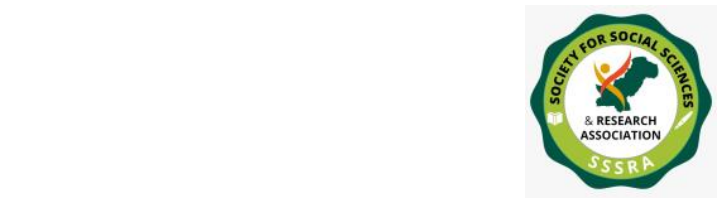

Pak. Journal of Int'L Affairs, Vol 4, Issue 2 (2021)

Analyzing Civil-Military Relations in ...

This was the beginning of military involvement in the politics of Pakistan (Khan, 2009:82). In the later history, Pakistani state has been influenced, either directly or indirectly, by the army. Direct military coups have been staged in 1958, 1969, 1977 and 1999 and, indirectly all civilian governments in Pakistan have been remained under the influence of the military.

The government of Junejo was overthrown in May, 1988 because; he had taken actions in clear disregards of the military when he replaced Major General Naik Mohammad with a civilian Aslam Hayat as Director Intelligence Bureau without informing Zia (Shafqat, 1997: 216); his signing of Geneva Agreement without the approval of Zia; independent inquiry on Ojri Camp incident and the replacement of Lieutenant General Sahibzada Yaqoob (Zia's protégé) by Zain Noorani as Foreign Minister (Shafqat, 1997: 217).

The government of Benazir Bhutto was overthrown in May, 1990 because; she had replaced the Inter-Services Intelligence (ISI)'s powerful chief, Lieutenant General Hamid Gul, and posted him as corps commander in Multan against the advice of the then Chief of the Army Staff (COAS) (Shafqat, 1997: 228); her move to influence the working of the Army's selection board and her trying to extend the term of Lieutenant General Alam Jan Mehsud corps commander in Lahore (Shafqat, 1997: 230; Sirohey, 2000: 367; Kukreja, 2003: 47, 228-9) proved detrimental for her premiership.

Likewise, the government of Nawaz Sharif was dissolved in 1993 because of the differences arose between Sharif and the army over the issue of sending Pakistani troops as part of the collective security action against Iraq's invasion of Kuwait in August 1990 (Rizvi, 2000b: 210-11); July 1991 statement of General Aslam Beg on the growing threat of war with India which Sharif was disagreed with; the appointment of Lieutenant General Javed Nasirby Sharif as Director General of the ISI against the wishes of the COAS (Rizvi, 2000b: 211); and the disagreement of the government and the army over the Operation Clean Up launched in the rural, and later urban, areas of Sindh (Rizvi, 2000b: 212). Nawaz Sharif was again ousted from the government in 1999 because he had interfered in the military high command (Aziz, 2008: 48; Siddiqi, 2012: 40), his peace initiative with India and stand on Kargil issue in 1999 were seen with suspicion by the military (Siddiqi, 2012: 40; Malik, 1996). Recently, the minister for information, Pervez Rashid was removed from office on account of Dawn leaks issue ${ }^{1}$ in October, 2016.

\footnotetext{
${ }^{1}$ An in-camera meeting was held between DG ISI, DG ISPR and Punjab Chief Minister, Shehbaz Shareef, in Lahore in October, 2016. The Dawn correspondent, Cyril Almeida, 


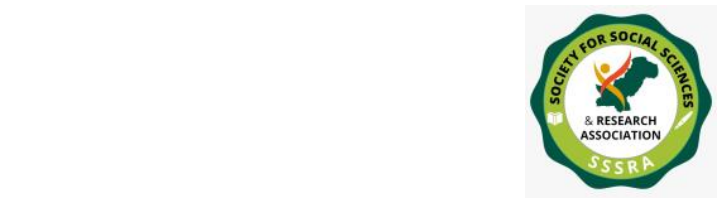

A similar contour of civil-military relations can also be seen in Turkey. The history of post-republican civil-military relations of Turkey unearths that there have been frequent military interventions in politics. The Turkish Armed Forces staged four direct interventions i.e. 1960, 1971, 1980 and 1997 (Ozpek, 2014). Besides, the Turkish military has become a major force in the economy and has affiliated itself with companies inside the society (Schlager \& Weisblatt, 2006: 1367-1380). Moreover, the military was so entrenched in the political, economic and social spheres of the Turkish society till 2002 that it was an uphill task for the civilians to keep them detached from politics. The NSC had an overwhelming control over the internal security and foreign policies of Turkey. Further, the military projected itself as a sacred institution and left no room for public criticism (Ozpek, 2014).

\section{Factors Influencing Civil-Military Relations in Pakistan and Turkey}

Various factors with similar nature have added to this strength of military in Pakistan and Turkey. Ideology is one of them. In Turkey, military is the custodian of Kemalism², while in Pakistan it is the guardian of state ideology i.e. Islam. Both the states' military have never compromised on the respective ideologies. The coup d,' etats of 1960, 1971, 1980 and 1997 in Turkey have been staged by military after feeling threats to the state ideology i.e. Kemalism (Schlager \& Weisblatt, 2006). Likewise, Zia ul Haq, the then military chief cum president of Pakistan, used to say that the armed forces of Pakistan are not only the guardians of the territorial frontiers of Pakistan but are also the custodian of ideological frontiers (Ullah, 2014).

Geographical importance of the two republics is another factor which has given prominence to the armed forces in their respective political systems. Pakistan is at the heart of Asia which connects three important regions of Asia i.e. South Asia, Central Asia and Middle East (Ali, 2009). In like manner, Turkey connects two continents i.e. Asia and Europe. Turkey occupies an extremely strategic location in the eastern Mediterranean, standing at the crossroads between Asia and Europe. During the cold war, Turkey was NATO's "Eastern flank" vis-a-vis the USSR; today it provides the road to the new republics in the Caucuses and Central Asia (Schlager \& Weisblatt, 2006).

The geographical locations had gained prominence in the Cold War. During the war, the great powers had been in search of an ally in the Middle East which was provided by

\footnotetext{
the following day issued a report of the meeting. The military considered it as clearly against its sanctity.

${ }^{2}$ Kemalism is the name ofthe six principles upon which the Turkish political system had been constructed in early 1930s. These are: republicanism, secularism, populism, statism, nationalism and reformism. 


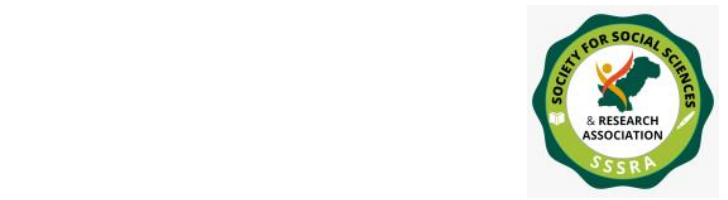

Pak. Journal of Int'L Affairs, Vol 4, Issue 2 (2021)

Analyzing Civil-Military Relations in ...

Turkey through CENTO, formerly Baghdad Pact, in 1955. Pakistan too joined Western defence pacts like Mutual Defence Assistance Agreement (MDAA), South East Asia Treaty Organization (SEATO) and Central Treaty Organization (CENTO) in September 1954 and 1955 respectively (Ali, 2009).

Another important peculiar factor which affected civil-military relationship in Pakistan and Turkey is Islamism and Islamic fundamentalism. Since the establishment of Turkey as a republic, the Islamists have been busy for having an Islamic political system. Today these Islamists and fundamentalist tendencies are reflected in the Gullenist movement in Turkey. In the case of Pakistan, several Islamists and fundamentalist movements are active like religious revivalists, Mujahedeen and Taliban. Moreover, separatists' elements are also busy in their demands for having separate identities and land for them i.e. Kurds in Turkey, while, Sindhis and Baluch in Pakistan.

Furthermore, the external and internal threats perceptions have also made Pakistan a security risk state. The existence of external threats from India and Afghanistan and internal threats in the form of religious extremism, communism, and ethnic ambitions has converted Pakistan into a security risk state. Internal and external threats in Turkey like Kurdish terrorist activities and Greece-Turkish scuffle on Cyprus had also affected the pattern of civil military relationship in Turkey before 2002 (Haq, 2012). Desh (1998) argues that greater external and internal threats negatively affect the civil-military relationship in a state.

Likewise, lack of democratic and developed political institutions, incompetent political leadership, and non-democratic character of the political parties have also paved way to military entrenchment in the politics of Pakistan and Turkey (Haq, 2012).

\section{Post-2002 Scenario and Civil-Military Relations in Pakistan and Turkey}

The dawn of $21^{\text {st }}$ century marked the era of divergence between the civil-military relationship of the two most identical nations. With the emergence of AKP in 2002, the pattern of civil military relationship in Turkey has undergone several changes.

The civilian institutions, through various reforms, are successful up to a greater extent in minimizing the role of the army. Tektas \& Kurt (2008) observe that new penal code has been adopted which has revised the anti-terror law and abolished the state security courts. The role of NSC has been reduced to an advisory/consultative body. In addition, its composition has also been changed in order to give majority to civilian members. Likewise, it has been decided that the post of Secretary General would no longer be 


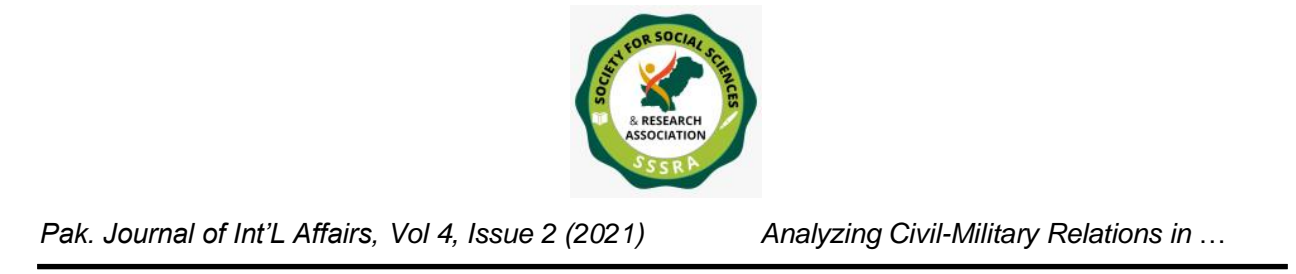

reserved exclusively for a military person. In order to enhance the transparency of defence expenditures, the court of auditors has been authorized to audit the accounts and transactions of all types of organizations, including the state properties owned by the armed forces. These reforms have dramatically reduced the dominance of military in Turkish politics which is evident from the abortive attempted coups of 2007 i.e. Ergenekon plot and July, 2016 (Kaya, 2011).

However, reforms like these have been unimaginable in Pakistan. Zulfiqar Ali Bhutto, an ex- prime minister of Pakistan, had once introduced certain military reforms which could not continue for longer time due to the regional politics (Rizvi, 1998). The regional security environment dramatically altered the civil-military relations and the military regained its earlier supremacy. By 1979, Russian forces entrance into Afghanistan had been declared a grave threat to Islam by the religious circles. The army in Pakistan which is the custodian of state ideology, i.e. Islam, took Russian intervention into account. Thus it got a higher position over the civilian institutions on issues of foreign policy (Rizvi, 2013).

Hence, the Turkish constitutional history, prior to 2002, has shown that toppling and dislodging civilian governments had been an easy job for the military. However, after 2002, with the emergence of AKP, the trajectory has been changed and now the civil institutions are gaining strength in running the affairs of the state. Now why Turkey has been successful in gaining civilian supremacy over military after 2002 ?

Various internal and external factors have contributed to this state of affairs in the post2002 period which are discussed in comparison with Pakistan.

\section{Performance of AKP}

Chowdhury (1988) argues that when civil institutions obtain mass support, the influence of the armed forces in politics can best be reduced. Popular support has provided a solid foundation to AKP for bringing social, economic and political reforms which have significantly affected civil-military relationship in Turkey (Keyman, 2012). AKP has won the hearts and minds of the people by addressing the economic crisis in 2002. Before 2002, Turkey was facing widespread unemployment, currency devaluation and low GDP. The party won 34.3 percent national vote and majority of seats in the Grand National Assembly (GNA) in the 2002 elections. Since the emergence of AKP, it has been successful in addressing the economic crisis. During AKP's rule per capita income has reached to $\$ 11,500$ and further infrastructural, educational and social development programmes have been undertaken (Cassano, 2011). 


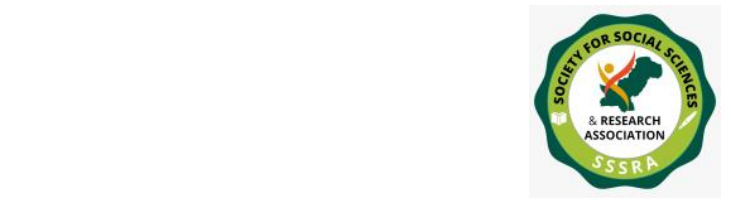

Pak. Journal of Int'L Affairs, Vol 4, Issue 2 (2021)

Analyzing Civil-Military Relations in ...

On the other hand, the military in Pakistan still exercise a dominant position mostly because the civilian governments have failed to deliver and establishing firm roots in the masses. The socio-economic conditions of Pakistan are not better. Hussain (2016) opines that poverty, hunger and illiteracy continue to haunt the land. And despite all their rhetoric, civilian leaders have done little to address these issues. That is why their right to govern has been challenged by Bonapartism.

\section{Continuity in Political Process}

AKP has assumed power in 2002 after winning 34.28 percent of the popular vote in the general election. That victory landed the party with two-thirds of the seats in Grand National Assembly (GNA) under an electoral law which limited parliamentary seats to political parties earning at least 10 percent of the popular vote (Gungor, 2008). AKP's victory was sweeping by the standards of Turkey, which was historically accustomed to rule by coalition governments. In July 2007 general elections, the party won another landslide victory. Since 1950, AKP is the only party which has gained 41.6 percent of votes and acquired 341 seats out of 550 in the Parliament (Gungor, 2008). Shortly after the election, on August 28, 2007, a party member, Abdullah Gül, was elected as the $11^{\text {th }}$ President of Turkey. AKP's continuous electoral successes continued till 2011 parliamentary elections where once again it obtained 49.83 percent of votes and 326 seats in the Parliament. Three times consecutive victories have made the party capable of bringing drastic reforms in the republic.

On the other hand, according to Ayub Jan, Assistant Professor of Political Science, University of Peshawar, continuity in political processes remained unseen in Pakistan. Neither of the political party in Pakistan has got continuous success in the elections like the AKP in Turkey. The political history of Pakistan shows that different political parties with different manifestos and programmes have won the elections held in Pakistan. He further said that continuation of political processes in Pakistan would make civilian institutions stronger and as a consequence military's influence in the political affairs will naturally diminish (personal communication, January 10, 2017).

\section{Factionalism in Military}

Different factions have emerged inside the Turkish military during 1970s. One group is known as absolutists also called as traditionalists and the other as gradualists also known as liberalists. The former is the proponent of status quo, while the latter is the advocate of liberalism. The liberals support a modern Turkey and thus back the AKP pro-west and 


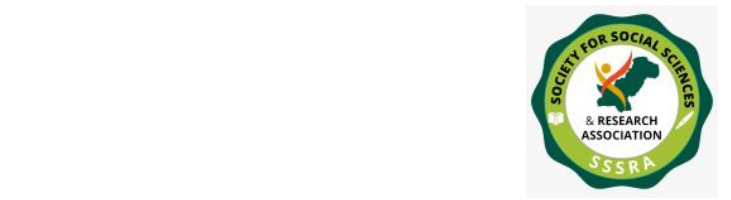

Pak. Journal of Int'L Affairs, Vol 4, Issue 2 (2021)

Analyzing Civil-Military Relations in ...

Europeanization policies (Aydinli, 2009). Bican Şahin is of the opinion that four factions have been observed inside the Turkish armed forces. These are (a) pro-NATO, (b) proChina, Russia and Iran, (c) Kemalists and (d) Islamists. He argued that though factionalism affects professionalism of the military, it provide the civilian government an opportunity to initiate stern reforms like civilian control over the armed forces. Moreover, factionalism within the military can hinder the possibilities of military interventions in

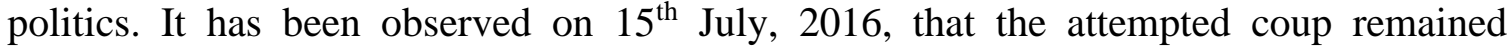
unsuccessful due to the existence of varying groups inside Turkish military (Personal Communication, January 9, 2017).

So long as one strong faction within the military remains committed to democracy, it can facilitate democratic progress and also assist in the extrication of the military from politics by allowing politicians to seize upon and exploit divisions within the military (Varol, 2013). Janowitz (1964) says armies with fractured or weak internal cohesion will have a lesser capacity to intervene in domestic politics. In Turkey, the civilian government under AKP found factionalism as a launching pad for bringing reforms in the system. The party picked up those likeminded officials from the top brass who did not oppose the Europeanization and democratization process in Turkey. Erdogan developed friendly relations with them and appointed them to important positions. Chief of Staffs, General Ozkok (2002-2006), General Buyukanit (2006-2009) and Basbug (2009) are those military generals who have never tried to sabotage the reforms process undertaken by AKP (Aydinli, 2012). Buyukanit's, Chief of Staff, statement reflects the gradualist faction outlook towards AKP government. He stated,

"On October 2007, the Prime Minister asked our opinions about the operation in Northern Iraq covered in the resolution. We submitted our opinion on 1st Nov 2007. Thereby, we communicated our proposal to the Prime Minister. The PM and Ministry of Foreign Affairs are currently working on these proposals. This will turn into a government directive, and will be transmitted to us. Indeed, that is the normal planning procedure. Now, the authority resides with the government. They will assess. If they deem that an operation is necessary, then they will say that 'such operation should be made', we now wait for the government directive. We will do what is necessary according to that directive. There is no delay in the process" 3 .

This statement of the Turkish military chief has clearly shown that gradualist faction in the military supports democratization and democratic control. 


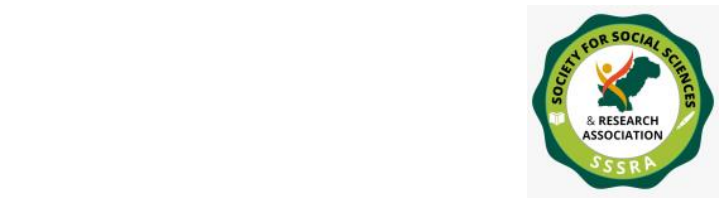

On the other hand, the armed forces in Pakistan strictly adhere to the principle of esprit de corps i.e. sense of oneness. Cohesion and oneness has been the distinguished feature of Pakistani military. Janowitz (1964) wrote that armies with high internal cohesion will have greater capacity to occupy a dominant position in the political system. The army in Pakistan is having a strong bond of oneness, hierarchy and spirit de corps (Rizvi, 1998). The relative strength of military in Pakistan has encouraged its intervention into politics and under its hegemonic control, no autonomous class, group or political structure has been allowed to function (Shafqat, 1997: 12).

\section{The Principle of Republicanism}

Republicanism, one of the six principles of Kemalism, implies rule of law, rights, equality, justice, liberty and public participation. These are the symbols of democracy which is replacing authoritarianism in Turkey (Keyman, 2012). The principles of republicanism and reformisms have promoted the recent reforms undertaken by AKP. Consequently, these two principles i.e. reformism and republicanism have put the military subservient to civilians who, since 2002, are deriving its strength from them.

As a comparison with Turkey, military in Pakistan derives its strength from the ideology of Pakistan. Ayub Jan stated that military is the sole protector of the ideology of Pakistan. He quoted Ayesha Jalal's guardianship myth ${ }^{4}$ as a tool which gives immense role to military in the internal and external policy making in Pakistan. He opined that this guardianship myth thinking inside military as an institution has made Pakistani military a sovereign body which is beyond any limitations (personal communication, January 10, 2017). Ijaz Khattak also discussed that military has always kept the protection of ideology of Pakistan as its highest duty. It does not compromise on the state ideology. Moreover, every act of the armed forces is justified in that direction (personal communication, January 11, 2017).

\section{European Union Accession}

Geographically Turkey is a gateway to Europe. Since 1990s, Turkey has been struggling to get membership of the European Union (EU) but the internal political mechanism and issues like human rights violation, lack of accountability, non-observance of the rule of law and unfriendly civil-military relations have hindered her bid for the membership

\footnotetext{
${ }^{4}$ Army in Pakistan is the guardian of state ideology i.e. Muslim identity. Army's every deed is justifiable in its bid of defending the ideology of Pakistan. For more on this see Jalal, A. (1990). State of Martial Rule, London: Cambridge University Press. 


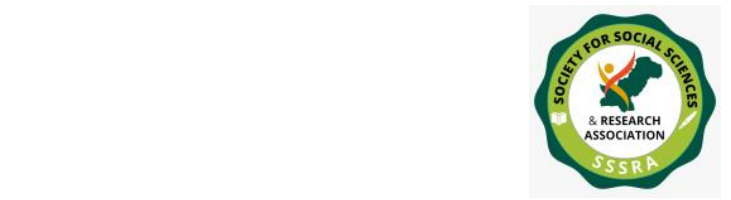

(Toktas \& Kurt, 2008). EU summit was held in Helsinki, capital of Finland, in 1999 in which Turkey's candidacy for the EU was conditioned with addressing the above issues. Hence, Europeanization and Turkey's quest provided for civilian supremacy in Turkey. The civilian governments in Turkey started reforms accordingly in the light of Helsinki and Copenhagen criteria ${ }^{5}$ (Karaosmanoglu, 2011).

The EU demanded that the position and role of the Chief of Staff would be minimized, structural changes were to be made in the NSC which meant numbers of civilian be increased, NSC would take a secondary role in the security affairs, state security courts were to be established, and limitations be imposed on laws regarding state of emergency (Keyman, 2012). Sheheryar Khan, a Pakistani scholar having expertise in Turkish politics, argued that AKP quickly embraced the proposed reforms after entering into Parliament in 2002. The AKP has been successful in bringing democratic reforms in the light of EU proposed criteria (personal communication, January 3, 2017).

On the other hand, Pakistan has not yet applied for such an organization which could stipulate conditions like EU. Though Pakistan is the member of several regional and international organizations like SAARC, OIC, NAM, ECO, these organizations, unlike EU, do not impose any condition concerning institutional reforms on its member states.

\section{International Support to AKP}

AKP has learnt a lesson from the past experiences of military adventurism in the republic. All the previous military intervention into politics had been caused particularly by the governments' Islamists leanings and policies (Toktas \& Kurt, 2010). Nevertheless, AKP is the conglomeration of traditionalists and innovationists. It was established in August 2001 as a result of the divide between 'traditionalists' and 'innovationists' within the Islamist Virtue Party (Ozcetin \& Ozer, 2015).

After the establishment of AKP, its leaders followed a deviation from the Islamist experiences and sought readjustment of its policies towards politics and religion. The party adopted a secular, liberal and moderate approach towards internal and external politics (Yilidirim, 2010). Moreover, this approach of AKP has significantly attracted the support of international community particularly the US and EU.

\footnotetext{
${ }^{5}$ In the summit Turkish bit for EU was conditioned to her respect to human rights, insurance of rule of law, friendly relations with neighbors, civilian control over military etc. 


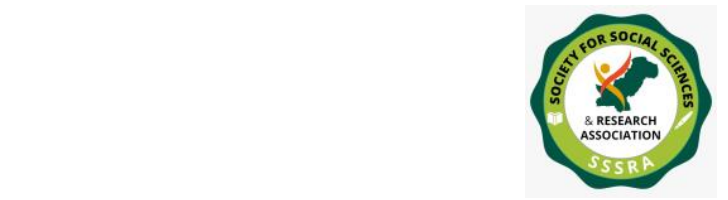

Pak. Journal of Int'L Affairs, Vol 4, Issue 2 (2021)

Analyzing Civil-Military Relations in ...

On the other hand, the major powers have most of the time supported military dictators in Pakistan (Ali, 2009; Zaidi, 2005). According to Murad Ali (2009) military in Pakistan have received enormous financial support from the west during the Cold War and the ongoing war against terrorism.

\section{External and Internal Threats}

Desch (1999) argues that external threats to a state greatly influence its civil-military partnership. He contends that lesser external and internal threats pave way to unpredictable civil military relationship. In other words, when a state is receiving lesser or no external and internal threats, the civilian control over the armed forces may either be weak or strong. In the case of Turkey the civilian control over the armed forces is gaining strength as evident from reforms undertaken by AKP, which has pushed the military back to barracks. According to Bican Şahin, the neighbouring countries do not pose any threat to the territorial integrity of Turkey. Cyprus has not remained a threatening issue any more between Turkey and Greece. President Erdogan has adopted a policy of friendship with his bordering countries. On internal threats he commented that Kurdish terrorist organization (PKK) had posed threats to the security of Turkey during $70 \mathrm{~s}$ and 80s. However, the Turkish armed forces have successfully overcome PKK terrorist activities (personal communication, January 9, 2017).

Unlike Turkey, Pakistan is surrounded by hostile neighbours. The strained relations of Pakistan with her neighbours, particularly India and Afghanistan, have always contributed to the supremacy of military in terms of policy formulation and implementation (Paris, 2010). Defence policy and national security have been the jurisdictions of military since the establishment of Pakistan. According to A.Z Hilali, Pakistan continuously receives threats from her bordering countries particularly India. Since her inception, India has been posing serious threats to the existence and territorial integrity of Pakistan. The military in Pakistan is considered as the only institution countering Indian threat perceptions. This threat perception from India has increased military influence in the domain of foreign policy of Pakistan (personal communication, January, 10, 2017). Currently, the internal security situation in Pakistan is presenting a grim picture. Sectarianism, militancy and terrorism have badly affected the law and order situation in Pakistan (Khan, 2009).

Thus the internal and external threat perceptions have greater impacts on the civilmilitary relationship of Turkey and Pakistan. In Turkey, the civilian government is gaining strength over the armed forces as a consequence of lesser internal and external 


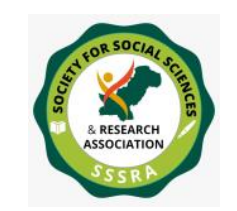

Pak. Journal of Int'L Affairs, Vol 4, Issue 2 (2021)

Analyzing Civil-Military Relations in ...

threats. On the other hand, military still enjoys a dominant position in the internal and foreign policies of Pakistan as a result of higher internal and external security threats.

\section{CONCLUSION}

To sum up, Pakistan and Turkey have mostly shared a common history of civil-military relationship. In the pre-independence and pre-republicanism periods of Pakistan and Turkey, civilian control had been the guiding mode of operations. Nevertheless, the principle of democratic control over the armed forces of Pakistan and Turkey disappeared in the post-independence and post-republicanism periods. Till 2002, both the republics have experienced the same pattern of civil-military relationship. They have witnessed four direct coups in their respective state politics. Indirectly, the armed forces of both the sates have influenced the formulation of foreign and defence policies. However, in the year of 2002 an era of divergence occurred in the civil-military relations of the two identical states. Turkey has been passing through a process of transformations in her pattern of civil-military relations. The civilians have acquired its control, through various constitutional reforms, over the armed forces. On the other hand, Pakistan is experiencing the same pattern and trend in the domain of civil-military relationships. Multiple factors like Europeanization, performance of AKP, continuity in political processes, lesser internal and external threats and factionalism inside military have made Turkey's successful journey towards bringing democratic control over her armed forces possible. The civilians in Pakistan are still having a Sisyphean task of bringing supremacy over the armed forces. The factors which have contributed to the application of democratic control in Turkey's civil-military relations are unfortunately missing in the case of Pakistan. Turkey provides a good example for Pakistan to imitate in the context of civilian supremacy and a way towards substantial democratization process. 


\section{References}

Ali, M. (2009). US foreign aid to Pakistan and democracy: An overview. Pakistan Journal of Social Science 29(2): 247-258.

Altunisik, M. B. (2008). The possibilities and limits of Turkey's soft power in the Middle East. Journal Insight Turkey, 10(2), 44-45.

Altunisik, M.B. (2010). Turkey reforms process. Retrieved fromwww.ucm.es/info/unisci/revistas/UNISCI\%20DP\%2023\%20$\%$ 20BENLI.pdf.

Avi, L. M. (2007). Civil-military relations in Turkey. Texas: Texas State University.

Aydinli, E. (2009). A paradigmatic shift for the Turkish General and an end to the coup era in Turkey. The Middle East Journal, 63(4): 581-596.

Aydinli, E. (2012). Civil-military relations transformed. Journal of Democracy, 23(1) Chambers, P. \& Croissant, A. (Ed.). (2010). Democracy under Stress: Civilmilitary relations in South and Southeast Asia. Thailand: Institute of Security and International Studies (ISIS).

Chowdhury, M. (1988). Pakistan: Its politics and bureaucracy. New Delhi: Associated Publishing House.

Desch, M. C. (1999). Civilian control of the military: The changing security environment. Baltimore.

Hussain, Z. (November 9, 2016). Change of army guard, The Dawn.

Janowitz, M. (1977). Military institutions and coercion in developing nations. Chicago: University of Chicago Press.

Jenkins, G. (2007). Continuity and change: Prospects for civil-military relations in Turkey. Journal of International Affairs, 2(3): 100-108.

Keyman, A. (2012). Civil-military relations in Turkey. Retrieved from http://www.ei.r.info/2012/05/21/civil-military. 
Khan, H. (2009). Constitutional and political history of Pakistan ( $2^{\text {nd }}$ ed.). Karachi: Oxford University Press.

Kukreja, V. (2003). Contemporary Pakistan: Political processes, conflicts and crises. New Delhi: Sage Publications.

Malik, I. H. (2008). The history of Pakistan. London: Greenwood.

Paris, J. (2010). Prospects for Pakistan. London: Legatum Institute.

Rizvi, H. A. (2000a). The military and politics in Pakistan (1947-97). Lahore: Sang-eMeel Publication.

Rizvi, H. A. (2000b). Military, state and society in Pakistan. London: Macmillan.

Schlager, N. \& Weisblatt, J. (Ed.). (2006). World encyclopaedia of political systems and parties, $\left(4^{\text {th }}\right.$ ed.). New York: Facts on File Inco.

Shafqat, S. (1997). Civil-military relations in Pakistan: From Zulfikar Ali Bhutto to Benazir Bhutto. Boulder, Colorado: Westview Press.

Siddiqa, A. (2007). Military Inc: Inside Pakistan's military economy. London: Oxford University Press.

Siddiqi, F. H. (2012). The politics of ethnicity in Pakistan: The Baloch, Sindhi and Mohajirs ethnic movements. London \& New York: Routledge.

Toktas, S. \& Kurt, M. (2008). The impacts of European Union reforms process on civilmilitary relations in Turkey. SETA Foundation for Political, Economic and Social Research, No. 26.

Varol, O. O. (2013). The Turkish model of civil-military relations. $1 \cdot C O N, 11(3)$ : $727-$ 750 . 
Wogu, L. \& Ibietan, J. (2014). Civil-military relations and leadership crisis in 21st Century Africa: An inquiry. International Journal of Innovative Social Sciences and Humanities Research 2(1): 48-61.

Yildirim, C. (2010). The role of the military in Turkish politics and European Union membership. Retrieved from http://www.balkanalysis.com/turkey/2010/12/02/therole-of-themilitary-in-turkish-politics-and-european-union-membershipnegotiations.

Zurcher, E. J. (2004). Turkey: A modern history. New York: Tauris \& Co. Ltd. 